\title{
A review on phytoremediation as an ecological method for in situ clean up of heavy metals contaminated soils
}

\author{
Nicolae Cioica *1 , CătălinaTudora ${ }^{2}$, Dorin Iuga ${ }^{2}$, György Deak ${ }^{4}$, Monica Matei ${ }^{4}$, \\ Elena Mihaela $\mathrm{Nagy}^{1}$, and Zoltan Gyorgy ${ }^{1}$ \\ ${ }^{1}$ INMA Bucharest, Branch Cluj-Napoca, 59 Al. Vaida Voievod Str., Cluj Napoca, Romania \\ 2 INMA Bucharest, 6 Ion Ionescu de la Brad Bd., Bucharest 1, Romania \\ ${ }^{3}$ IBA Bucharest, 5 Baneasa Ancuta, Bucharest 2, Romania \\ ${ }^{4}$ INCDPM Bucharest, 294 Splaiul Independentei, Bucharest 6, Romania
}

\begin{abstract}
Heavy metals are among the most common types of contaminants in agricultural soils, especially those bordering the cities, due to the uncontrolled use of sewage sludge, compost, mining waste and chemical fertilizers. Excessive accumulation of heavy metals, which do not degrade over time, adversely affects crop yields by decreasing microbial activity and fertility of contaminated soils. Also, excess of heavy metals in the soil poses a serious threat to plant and animal health and, through their entry into the food chain, to human health. For this reason, the decontamination of soils contaminated with heavy metals has become a necessity. This review presents the current state of phytoremediation research as the most cost-effective method of in-situ environmental decontamination of soils contaminated with heavy metals.
\end{abstract}

\section{Introduction}

The phenomenon of urbanization, rapid industrialization and intensive farming in recent decades has led to the accumulation of a significant amount of heavy metals both in agricultural land bordering the cities and in the countryside because of uncontrolled disposal of household waste, treatment sludge, mining waste and the excessive use of chemical fertilizers. The accumulation of heavy metals, which do not degrade over time, some of them $(\mathrm{Cd}, \mathrm{Pb}, \mathrm{Hg})$ being toxic in any quantity, however small and others $(\mathrm{Zn}, \mathrm{Cu}, \mathrm{Mn}, \mathrm{Mo}, \mathrm{Ni}$, $\mathrm{Co}$ ) being beyond acceptable levels as essential micronutrients adversely affecting crop yields by decreasing microbial activity and fertility of contaminated soils. Also, excess of heavy metals in the soil poses a substantial danger to plant and animal health and, through their entry into the food chain, to human health [1-7]. For this reason, the decontamination of soils contaminated with heavy metals has become a necessity.

Decontamination can be done by conventional methods (chemical or physical) or by biological methods (plants, algae, microorganisms, etc.).

${ }^{*}$ Corresponding author: ncioica@yahoo.com 
Conventional technologies produce different pollutants and are unprofitable [1].

Of the various biological technologies existing so far, phytoremediation, as a technology based on solar energy, is considered the most environmentally friendly and very cost-effective. Phytoremediation, also called botanical bioremediation, is an ongoing research area and consists in reducing or eliminating the toxic effects of heavy metals in contaminated soils by their assimilation or immobilization by some specially selected green plants, with the help of associated microorganisms in the soil [8].

Depending on the response to the presence of heavy metals in the soils where they grow or are grown, the plants can be divided into three categories [9]:

- exclusion plants, which limit the access of heavy metals from soil only to roots and restricts the transport and assimilation into their aerial parts. Such plants can be used as phytostabilisers;

- bioindicators, in the case of which the absorption and transport of heavy metals to their aerial parts is regulated so that the concentration of heavy metals in the plant reflects the concentration of heavy metals in the soil. They have a limited extraction potential and are used to biologically monitor soil contamination;

- accumulators which allow the access, transport and entry of heavy metals from soil into their aerial parts to a level which does not affect their health and normal development. Of these, there are hyperaccumulating plants that can concentrate large quantities of heavy metals in their aerial parts, being successfully used for the remediation, by phytoextraction, of soils contaminated with heavy metals.

\section{Phytoremediation techniques applied to soils contaminated with heavy metals}

Depending on the way of fixing, absorbing, accumulating or eliminating the heavy metals by the plants used, there are three phytoremediation techniques applicable for the remediation of soils contaminated with heavy metals: phytoextraction, phytostabilisation and phytovolatilisation, the mechanism of which is presented in Figure 1.

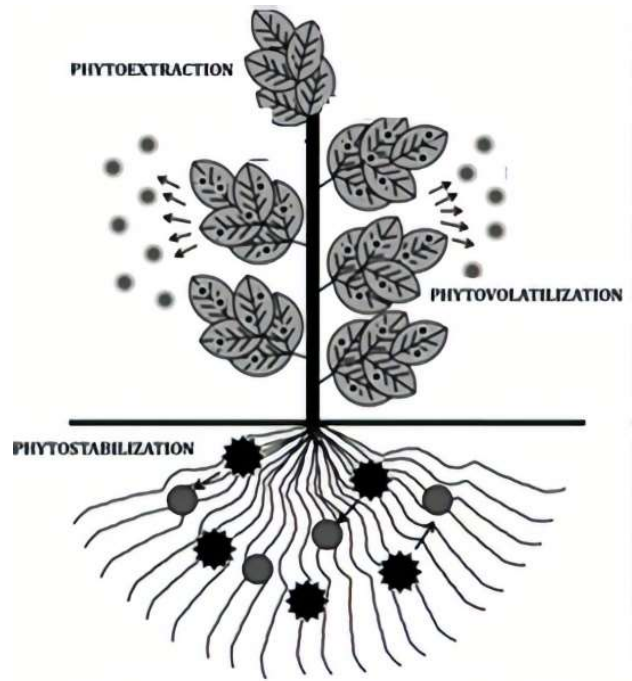

Fig.1 Phytoremediation strategies for soils 


\subsection{Phytoextraction}

Soil remediation by phytoextraction implies the absorption of the contaminant through plant roots, its transport and subsequent accumulation in its aerial parts, followed, at the appropriate time, by harvesting and clearing the ground of plant biomass. Plants are sown or transplanted into the soil contaminated with heavy metals and then maintained by appropriate agricultural practices. The roots of these plants absorb, from the soil, the soluble compounds resulting from the processing by the soil microorganisms of the metals and translocate them to the aerial shoots where they accumulate. After sufficient development, the aerial parts of the plants are harvested and cleared, resulting in permanent removal of heavy metals from contaminated soils.

A large number of researches indicate that there are many hyperaccumulating metallophyte plant species that have a tremendous genetic potential for removing toxic metals from the soil so that they can play a major role in the phytoextraction process [10].

These include approximately 20 hyperaccumulators for $\mathrm{As}, 10$ for $\mathrm{Cd}, 14$ for $\mathrm{Pb}, 30$ for $\mathrm{Co}, 34$ for $\mathrm{Cu}, 320$ for $\mathrm{Ni}, 30$ for Se, 11 for $\mathrm{Zn}$ and 10 for $\mathrm{Mn}[11,12]$.

Table 1 presents a part of the hyperaccumulating metallophyte plants that have been studied and presented in the literature, some with a high phytoextraction yield both in terms of the number and amount of heavy metals assimilated.

Table1. Hyperaccumulating plants used to study the phytoremediation of soils contaminated with heavy metals

\begin{tabular}{|l|l|l|}
\hline \multicolumn{1}{|c|}{ Plant } & \multicolumn{1}{|c|}{ Heavy metal } & Refences \\
\hline Arabidopsis halleri & $\mathrm{Zn}$ & {$[13]$} \\
\hline Thalaspi caerulescene & $\mathrm{Zn}$ & {$[14]$} \\
\hline Brassica juncea L. & $\mathrm{Cu}, \mathrm{Zn}, \mathrm{Pb}$ & {$[15,16,17,18,19]$} \\
\hline Brassica napus L. & $\mathrm{Cu}, \mathrm{Zn}, \mathrm{Pb}$ & {$[16,20]$} \\
\hline Brassica oleracea, Raphanus sativus & $\mathrm{Zn}, \mathrm{Cd}, \mathrm{Ni}, \mathrm{Cu}$ & {$[1,21]$} \\
\hline Cardaminopsis halleri & $\mathrm{Zn}, \mathrm{Pb}, \mathrm{Cu}, \mathrm{Cd}$ & {$[22]$.} \\
\hline Cicer aeritinum L. & $\mathrm{Cd}, \mathrm{Pb}, \mathrm{Cr}, \mathrm{Cu}$ & {$[23,24,25]$} \\
\hline Cucumis sativus L. & $\mathrm{Pb}$ & {$[15]$} \\
\hline Eichhornia crassipes L. & $\mathrm{Cr}, \mathrm{Zn}$ & {$[26]$} \\
\hline Euphorbia cheiradenia & $\mathrm{Pb}, \mathrm{Zn}, \mathrm{Cu}, \mathrm{Ni}$ & {$[27]$} \\
\hline Helianthus annuus Sunflower) & $\mathrm{Pb}, \mathrm{Cd}$ & {$[28]$} \\
\hline Jatropha curcas L. & $\mathrm{Cu}, \mathrm{Mn}, \mathrm{Cr}, \mathrm{As}, \mathrm{Zn}, \mathrm{Hg}$ & {$[29]$} \\
\hline Lantana camara L. & $\mathrm{Pb}$ & {$[30]$} \\
\hline Lavandula vera L. & $\mathrm{Pb}$ & {$[31]$} \\
\hline Lens culinaris Medic. & $\mathrm{Pb}$ & {$[32]$} \\
\hline Lepidium sativum L. & $\mathrm{As}, \mathrm{Cd}, \mathrm{Pb}$, & {$[33]$} \\
\hline Lactuca sativa L. & $\mathrm{Cu}, \mathrm{Mn}, \mathrm{Zn}, \mathrm{Ni}, \mathrm{Cd}, \mathrm{Pb}, \mathrm{Co}$ & {$[34,35]$} \\
\hline Miscanthus $x$ giganteus & $\mathrm{Cu}, \mathrm{Ni}, \mathrm{Pb}, \mathrm{Zn}$ & {$[36]$} \\
\hline Oryza sativa L. & $\mathrm{Cu}, \mathrm{Cd}$ & {$[37]$} \\
\hline Minuartia verna, Agrostis tenius & $\mathrm{Pb}$ & {$[14]$} \\
\hline Pelargonium & $\mathrm{Pb}$ & {$[38,21]$} \\
\hline Pisum sativum L. & $\mathrm{Pb}, \mathrm{Cu}, \mathrm{Zn}, \mathrm{Ni}, \mathrm{As}, \mathrm{Cr}$ & {$[39,40,41]$} \\
\hline Potentilla griffithii & $\mathrm{Zn}$ & {$[42]$} \\
\hline Rapanus sativus L. & $\mathrm{Cd}, \mathrm{Fe}, \mathrm{Pb}, \mathrm{Cu}$ & {$[33]$} \\
\hline Salvia sclarea L. & $\mathrm{Pb}, \mathrm{Cd}, \mathrm{Zn}$ & {$[31]$} \\
\hline Spinacia oleracea L. & $\mathrm{Cu}, \mathrm{Ni}, \mathrm{Pb}, \mathrm{Zn}, \mathrm{Cr}$ & {$[43]$} \\
\hline Sorghum bicolor L. & $\mathrm{Cd}, \mathrm{Cu}, \mathrm{Zn}$ & {$[44,45,46]$} \\
\hline Trifolium alexandrinum & $\mathrm{Zn}, \mathrm{Pb}, \mathrm{Cu}, \mathrm{Cd}$ & {$[47]$} \\
\hline Viola principis & $\mathrm{Pb}$ & {$[48]$} \\
\hline Zea mays L. & $\mathrm{Cd}, \mathrm{Pb}, \mathrm{Zn}, \mathrm{Cu}$ & {$[43,49,50]$} \\
\hline & & \\
\hline
\end{tabular}


Compared to common plants, hyperaccumulating metallophyte species are able to accumulate heavy metals, in their aerial parts, in quantities of 100-500 times larger than normal plants, without effect on their development performance [51]. There are no general standards to establish the level of heavy metals from which metallophytes are considered to be hyperaccumulators [52]. Contaminant levels that different types of hyperaccumulating metallophytes are able to accumulate differ for different metals. The authors of a recent review on the subject consider that the species of plant which, when grown on soils contaminated with heavy metals, accumulate in their aerial parts, in relation to the dry matter, $>10,000 \mathrm{mg} / \mathrm{kg} \mathrm{Mn}$ and $\mathrm{Zn},>1000 \mathrm{mg} / \mathrm{kg} \mathrm{Cu}, \mathrm{Ni}, \mathrm{As}$ and $\mathrm{Pb}$ or $>100 \mathrm{mg} / \mathrm{kg} \mathrm{Cd}$ and Se, are part of the hyperaccumulating metallophytes category [53].

The potential of hyperaccumulating metallophyte species to absorb and accumulate heavy metals is of great ecological importance. Mechanisms of heavy metal hyperaccumulation comprise biochemical and biophysical transformations. Unfortunately, these mechanisms and the processes involved in the accumulation of metals are still little studied in depth and the mechanism of physiological transformations are not entirely known [52]. Some recent research on physiological hyperaccumulation processes has partly explained the mechanisms involved in metal hyperaccumulation.

There are two parameters that indicate the efficiency of phytoextraction. The first is the bioconcentration factor that indicates the efficacy of a plant species to accumulate a heavy metal from the contaminated soil in its tissues and is expressed by the ratio of the concentration of the metal accumulated in the harvested plant biomass to the concentration of the same metal in the soil. The second factor is the translocation factor that indicates plant efficiency in translocating accumulated metal from roots to shoots and is expressed as the ratio of the metal concentration in plant shoots to the metal concentration in plant roots [54]

A successful phytoextraction is conditioned by increased values of these two parameters, combined with increased metal xylem loading and detoxification of metals in plants [9]. Physiological studies showed that heavy metal xylem loading and its transfer to aerial parts of plants is mediated by a series of transport proteins that are in most cases found in plasma or intracellular membranes [52]. Also, the tolerance for heavy metals absorption of hyperaccumulating metallophytes is given by the type and amount of chelators, such as the phytochelatins and metallothioneins, they contain and which contribute decisively to detoxification by vacuole sequestration of heavy metals $[55,56]$.

Once the mechanisms and factors that govern the absorption and transport capacity of metallophyte plants are known, one can proceed to the mathematical modeling of heavy metal bioaccumulation $[57,58]$. Mathematical modeling of heavy metal bioaccumulation seeks to know the mechanisms of this process and to identify ways to limit or optimize the bioaccumulation and phytoremediation processes [59]. The model can predict the optimal harvesting as well as the subsequent use of these metallophytes depending on the plant type and absorption of heavy metals [59].

Plants used in phytoextraction must have some special features including: high growth rate, large volume of aerial biomass, broadly distributed and highly branched root system [47], supraunitary, as high as possible, bioconcentration factor and translocation factor of target heavy metals from soil, high tolerance to the toxic effects of target heavy metals, good adaptation to environmental and climatic conditions in the respective area, increased resistance to pests and pathogens, easy cultivation and harvesting, aversion for herbivores in order to avoid contamination of the food chain $[47,55]$

Although phytoextraction leads to a permanent removal of metal from contaminated soils, phytoextraction is especially recommended for those soils that are contaminated with heavy metals at moderate levels, as most plant species are not capable to decontaminate heavily polluted soils [60]. For instance, phytoextraction can be applied for $\mathrm{Pb}$ decontamination by 
Brassica juncea only for soils having a $\mathrm{Pb}$ contamination degree less than $1500 \mathrm{mg} / \mathrm{kg}$ [52, 61]

Like metallophyte plants, there are also metallophyte algae that also have a large capacity to absorb heavy metals and so there is appreciable potential to use them to remove heavy metals from polluted soils.

Table 2 presents some algae species that researchers used to remove heavy metals from contaminated sites.

Table 2. Soil algae used in the study on phytoremediation of soils contaminated with heavy metals

\begin{tabular}{|l|l|l|}
\hline \multicolumn{1}{|c|}{ Alga } & \multicolumn{1}{|c|}{ Heavy metal } & References \\
\hline Ascophyllum nodosum & $\mathrm{Ni}, \mathrm{Pb}$ & {$[62]$} \\
\hline Cladophora fascicularis & $\mathrm{Pb}(\mathrm{II})$ & {$[63]$} \\
\hline Cladophora glomerata & $\mathrm{Zn}, \mathrm{Cu}$ & {$[64]$} \\
\hline Cladophora glomerata, Oedogonium rivulare & $\mathrm{Cu}, \mathrm{Pb}, \mathrm{Cd}, \mathrm{Co}$ & {$[65]$} \\
\hline Cymodocea nodosa & $\mathrm{Cu}, \mathrm{Zn}$ & {$[66]$} \\
\hline Fucus vesiculosus, Laminaria japonica & $\mathrm{Zn}$ & {$[67]$} \\
\hline Oscillatoria quadripunctulata, Oscillatoria tenius & $\mathrm{Cu}, \mathrm{Pb}$ & {$[68]$} \\
\hline Sargassum filipendula & $\mathrm{Cu}$ & {$[69]$} \\
\hline Sargassum natans & $\mathrm{Pb}$ & {$[62]$} \\
\hline Spirogyra hyalina & $\mathrm{Cd}, \mathrm{Hg}, \mathrm{Pb}, \mathrm{As}$ & {$[70]$} \\
\hline
\end{tabular}

Possible mechanisms for heavy metal tolerance, adsorption, transport and storage vary depending on various factors such as algal anatomy and growth medium [1]. In the case of algae, metal ions are adsorbed over the cellular surface by physical adsorption and then they are slowly transported into the cytoplasm by chemisorption [62].

\subsection{Phytostabilisation}

Soil depollution through phytostabilisation involves the use of certain plant species to immobilize contaminants in the soil and groundwater by absorption and accumulation in plant tissues, root adsorption or precipitation in the root area, which prevents their migration to the soil as well as their displacement through erosion and deflation $[25,71,72]$. Thus, unlike phytoextraction, phytostabilisation does not have the role of decontaminating the soil but is intended to reduce environmental contamination.

For phytostabilisation, it is especially recommended to use exclusion plants that allow heavy metals from soil to enter only in their roots, protecting their aerial parts against contamination with these metals. Such metallophytes are the Agrostis tenius and Festuca rubra plant species used for the phytostabilisation of soils contaminated with $\mathrm{Pb}, \mathrm{Zn}$ and $\mathrm{Cu}$ [73]. It was also found that in the rhizosphere zone of the Silene vulgaris and Agrostis capilaris species $\mathrm{Cd}$ forms compounds with sulphides and $\mathrm{Pb}$ is converted into insoluble product as phosphate, which recommends them as phytostabilisers on the land contaminated with these heavy metals [14, 52].

To enhance the immobilization of heavy metals in the soil, phytostabilisation can be applied together with other decontamination methods, such as the application of organic amendments that increase the number of roots and multiplication of microorganisms in the contaminated soil $[1,52]$.

Studies on medicinal and aromatic plants showed that some of them such as Ocimum basilicum L., Melissa Officinalis L., Valeriana officinalis L., Calendula officinalis L. and Matricaria chamomilla $L$. are exclusion plants for $\mathrm{Pb}, \mathrm{Zn}$ and $\mathrm{Cd}$, which recommends them to be used for the phytostabilisation of soils contaminated with these metals $[34,74]$. 
Alimurgic species, which are edible wild plants that grow spontaneously in natural pastures, can also be used as phytostabilisers: Cichorium intybus L., for soils contaminated with $\mathrm{Zn}$, and Taraxacum officinale for soils contaminated with $\mathrm{Cd}$ [75].

\subsection{Phytovolatilisation}

Phytovolatilisation is a phytoremediation technique in which plants absorb volatile metallic contaminants from the soil and metabolically processed them into less toxic compounds, which then, through the process of plant transpiration, are released as vapours into the atmosphere [22]. This technique is applicable among heavy metals for $\mathrm{Hg}$ and in the case of metalloids for Se and As, but there are few studies that demonstrated the performance of applying this technique to remedy contaminated soils [8].

Gaseous transformation of heavy metals from contaminated soil is based on specific mechanisms that are coordinated within plants by certain specific enzymes or genes.

Brassica juncea and Arabidopsis thaliana are capable of making the conversion of inorganic Se into organic selenoaminoacids (selenomethionine and selenocysteine) followed by biomethylation to form dimethyl selenide or dimethyl diselenide which are volatile and can be released into the atmosphere $[52,76]$.

However, there are few metallophyte plants that are naturally capable of transforming metals into volatile form. Therefore, in order to increase the ability to volatilize heavy metals, a number of genetically modified plants have been made [14].

\section{Optimizing phytoremediation of soils contaminated with heavy metals}

From the information presented so far, it results that phytoremediation techniques applicable to soils polluted with heavy metals have a depollution potential that can be used for practical purposes. However, there is a great need to improve these techniques, which can be achieved by optimizing agricultural practices, chemical assistance of phytoremediation and the association of metallophyte plants with microbial strains [77].

Optimizing agricultural practices refers to both land preparation and plant cultivation as well as to the maintenance and harvesting of the plant aerial part in the case of phytoextraction. Soil preparation consists of performing operations to ensure optimal density and aeration, as well as water drainage. While some crops are sown directly in the field, there are others where seedlings must be obtained that can be planted in the field in spring when there is no longer a frost hazard. Given the unfavourable conditions for plant germination in soils polluted with heavy metals, it is recommended that the seed density be doubled compared to the one used in standard agriculture [78]. Crop maintenance during plant growing consists of weed and pest control, fertilization and irrigation depending on the weather conditions and the water needs of the crops. As one of the objectives of the phytoextraction is to ensure an aerial part mass as large as possible, the optimal harvesting periods for phytoremediation crops may differ from the harvesting periods considered suitable for conventional agricultural purposes. Crop rotation and the practice of associated crops are also important ways to increase the phytoremediation yield of soils contaminated with heavy metals [79].

Chemical assistance of phytoremediation consists of the use of synthetic chelating agents such as ethylenediaminetetraacetic acid (EDTA),

$\mathrm{N}-(2-$ Hydroxyethyl)ethylenediaminetriacetic acid (HEDTA), diethylenetriaminepentaacetic acid (DTPA) and ethylenediamine-N,N'-bis(2-hydroxyphenylacetic acid) EDDHA which increase the amount of heavy metal assimilable by plants from the soil and thereby improve 
phytoextraction yield $[11,77]$. It has to be noted that the excessive use of this type of synthetic chelates can lead to an increase in the concentration of heavy metals in levigations collected in the area under the plant roots and it is therefore recommended to use other chelating agents such as nitrilotriacetic acid (NTA) or citric acid [80].

The association of metallophyte plants with microbial strains improve the precipitation, reduction, oxidation and absorption of heavy metals in the soil and help plants developing suitable even under conditions of heavy metal stress [14, 52].

In the literature, these strains are called metallophyte growth-promoting rhizobacteria. It has been found that heavy metal-resistant microorganisms protect plants from the harmful effects of heavy metal and even increase the absorption of metals by hyperaccumulating plants.

Many studies provided evidence that the association of microorganisms with rhizosphere leads to a yield of heavy metal accumulation in hyperaccumulating metallophytes up to 4 times higher compared to yields obtained in sterilized soil [81].

Table 3 shows some species of microbial strains that researchers used for microbial assisted phytoremediation.

Table 3. Microbial strains used in the study of microbial assisted phytoremediation

\begin{tabular}{|l|l|l|}
\hline \multicolumn{1}{|c|}{ Microorganism } & \multicolumn{1}{|c|}{ Heavy metal } & References \\
\hline $\begin{array}{l}\text { Aspergillus niger, Aspergillus awamori, Aspergillus } \\
\text { ussamii, Rhizopus delemar, Penicillium brevicompactum, } \\
\text { Saccharomycopsis lipolytica, Candida blankii, } \\
\text { Saccharomyces cerevisiae, Hansenula schneggie, } \\
\text { Debaromyces senii }\end{array}$ & $\mathrm{Co}, \mathrm{Cd}, \mathrm{Cu}, \mathrm{Zn}$ & {$[82]$} \\
\hline Pseudomonas veronii & & \\
\hline Kocuria flava & & \\
\hline Yarrowia lipolytica & $\mathrm{Cd}, \mathrm{Zn}, \mathrm{Cu}$ & {$[83]$} \\
\hline Geobacillus toebii subsp. Decanicus & $\mathrm{Cu}$ & {$[83]$} \\
\hline Bacillus cereus Bacillus subtilis & $\mathrm{Cd}, \mathrm{Ni}, \mathrm{Co}, \mathrm{Zn}$ & {$[84]$} \\
\hline
\end{tabular}

The two main techniques for the microbial inoculation of the rhizosphere are soil drainage and direct inoculation with microorganisms of seeds or plant roots before sowing or planting [87].

Bacteria introduced into the contaminated soil increase the mobility and bioavailability of heavy metals in it by lowering the $\mathrm{pH}$, increasing soil redox potential, producing plant growth stimulants and chelating compounds of heavy metals such as biosurfactants, organic acids, siderophores. [52, 88].

\section{Conclusions}

Phytoremediation is an ecological and very cost-effective technology, based on solar energy and aims at reducing or eliminating the toxic effects of heavy metals in contaminated soils by their assimilation or immobilization by some green plants or algae.

In the case of heavy metals, phytoremediation can be achieved by phytoextraction, phytostabilisation or phytovolatilisation, techniques that differ in the way the plant reacts to the contaminant.

Studies in the field showed that phytoremediation efficiency depends on many soil, contaminant and plant characteristics such as soil physicochemical properties, the bioavailability of heavy metals in the soil, the type and amount of exudates released by microorganisms and plant roots as well as the capacity of plants to take over, translocate, accumulate and detoxify these metals. 
To improve phytoremediation efficiency, use of genetically modified metallophyte plants, optimization of agricultural practices, chemical assistance of phytoremediation and association of metallophyte plants with microbial strains are sought.

\section{Acknowledgements}

This work was supported by Ministry of Research and Innovation, Projects code: PN-III-P4-ID-PCE2016-0860, PN-III-1.2-PCCDI/Contract 11/31.03.2018 and Core Program/Contract 5N/07.02.2019.

\section{References}

1. K. K. Yadav, N. Gupta, V. Kumar, J.K. Singh, Indian J. Environmental Protection, 37, 65 (2017)

2. A. Pruteanu, M. Hărmănescu, V. Vlăduţ, A. Muscalu, E. Marin, Annals of the University of Craiova - Agriculture, Montanology, Cadastre. 45(2) (2015)

3. A. Pruteanu., D. M. Bordean., I. Voicea, V. Vlăduţ, I. Gageanu, Proceedings of the 18th International Multidisciplinary Scientific GeoConference SGEM, 18 (2018)

4. A. Pruteanu, D. M. Bordean, N. Vrînceanu, V. Vlăduț, M. Niţu, I. Găgeanu, I. Caba, Annals of the University of Craiova - Agriculture, Montanology, Cadastre. 48(2) (2018)

5. A. Pruteanu, D.M Bordean, V. Vlăduţ, Proceedings of the 47 International Symposium Actual Tasks on Agricultural Engineering, 135 (2019)

6. P. Ekta, N. R. Modi, J Pharmacogn Phytochem, 7(4), 1485 (2018)

7. M.J.A. Ali, O. Al-Tamimi, Open Science Journal 3(1), 1 (2018)

8. A. Sumiahadi, R. Acar, IOP Conf. Series: Earth and Environmental Science, 142, 1 (2018)

9. A. J. M. Baker, P. L. Walke, J Plant Nutr. 3, 643 (1989)

10. T. Jakovljević, I. R. Redovniković, A. Laslo, Zastita Materijala, 57 (3), 496 (2016)

11. M. Ghosh, S.P. Singh, Appl. Ecol. Environ. Res. 3(1), 214 (2005)

12. N. K. Niazi, B. Murtaza, I. Bibi, M. Shahid, J. C. White, M.F. Nawaz, S. Bashir, G. Murtaza, Environmental Materials and Waste: Resource Recovery and Pollution Prevention (Academic Press, Cambridge, 2016)

13. F. J. Zhao, E. Lombi, T. Breedon, S.P. McGrath, Plant Cell and Environment, 23, 507 (2000)

14. A. Vasavi, R. Usha, P.M. Swamy, Jr. of Industrial Pollution Control 26 (1), 83 (2010)

15. R. Takeda, Y. Sato, R. Yoshimura, S. Komemushi, A. Sawabe, Proceedings of the Annual International Conference on Soils, Sediments, Water and Energy, 11, 293 (The Barkeley Electronic Press, 2006)

16. M. Turan, A. Esringu, Plant Soil Environ., 53(1), 7 (2007)

17. A. Singh, M. H. Fulekar, The Plant Family Brassicaceae: Contribution Towards Phytoremediation, (Springer Science+Business Media, Amsterdam, 153, 2012)

18. G. N. Koptsik, Eurasian Soil Sci., 47, 923 (2014)

19. H. Sharma, Phytoremediation of lead using Brasica juncea and Vetiveria zizanoides, Int. J. Life Sci. Res., 4(1), 91 (2016)

20. J. Park, J-Y. Kim, K-W. Kim, Geosystem Engineering, 15(1), 10 (2012)

21. A. J. M. Baker, R. D. Reeves, S. P. McGrath, In situ Bioremediation: Applications and investigations for hydrocarbon and contaminated sites remediation (ButterworthHeinemann, London 1991)

22. S. Sharma, S. Tiwari, A. Hasan, V. Saxena, L. M. Pandey, 3 Biotech., 8(4), 1 (2018)

23. P. A. Wani, M. S. Khan, A. Zaidi, Australian J. Exp. Agric., 47, 712 (2007)

24. P. S. Satvat, A. B. Mahinrakar, IJTES, 2(3), 338 (2011)

25. S. Dasgupta, P. S. Satvat, A. B. Mahinrakar, IJTES 2(3), 238 (2011)

26. V. K. Mishra, B. D. Tripathi, J. Hazard Mater, 164, 1059 (2009)

27. A. Chehregani, B.E. Malayeri, Int. J. Agric. Bio. 9 (3), 462 (2007) 
28. K. A.Alaboudi, B. G..Ahmed, Annals of Agricultural Sciences, 63(1), 123 (2018)

29. S. K. Yadav, A. S. Juwarkar, P. Kumar, P. R. Thawale, S. K. Singh, T. Chakrabarti, Biosource Tech., 100, 4616 (2009)

30. F. O. Alaribe, P. Agamuthu, Ecological Engineering, 83, 513 (2015)

31. V. R. Angelova, Proceedings of the XV Balkan Mineral Processing Congress, Sozopol, Bulgaria, 1045 (2013)

32. P. A. Wani, M. S. Khan, Bacteriology J., 2(4), 66 (2012)

33. S. Gunduz, F. N. Uygur., I. Kahramanoglu, Herald J. Agric. Food Sci. Res., 1(1), 1 (2012)

34. A. K. K. Achakzai, Z. A. Bazai, S. A. Kayani, J. Bot. 43(6), 53 (2011)

35. A. K. Quainoo, A. Konadu, M. Kumi, J. Bioremed. Biodeg. 6(1), 1 (2015)

36. A. Kocoń, B. Jurga, Environ Sci Pollut Res. 24, 4990 (2017)

37. P. Li, X. Wang, T. Zhang, D. Zhou, Y. He, J. Environ. Sci., 20, 449 (2008)

38. M. Arshad, J. Silvestre, E. Pinelli, J. Kallerhoff, M. Kaemmerer, A. Tarigo, M. Shahid, M. Guiresse, P. Pradere, C. Dumat, Chemosphere 71, 2187 (2008)

39. A. Malecka, A. Piechalak, I. Morkunas, Acta Physiol Plant, 30, 629 (2008)

40. A. Hegedusova, S. Jakabova, A. Vargova, O. Hegeus, T. J. Pernyeszi, Nova Biotechnologica, 9(2), 125 (2009)

41. S. Sharma, P. Sharma, P. Mehrotra, JAmSci. 6(6), 43 (2010)

42. P. J. Hu, R. L. Qiu, P. Senthilkumar, D. Jiang, Z. W. Chen, Y. T. Tang, F. J. Liu, Environ. Exp. Bot., 66, 317 (2009)

43. M. R. Abhilash., S. Srikantaswamy, D. Shiva Kumar, K. Jagadish, L. Shruthi, Int. J. Applied Sci. 4(1), 129 (2016)

44. A. P. Pinto, A. M. Mota, A. de Varennes, F. C. Pinto, Sci Total Environ. 326, 239 (2004)

45. V. R. Angelova, R. V. Ivanova, V. A. Delibaltova, K. I. Ivanov, J. Agric. Sci. Technol. JAST-A, 1(5) 693 (2011)

46.S. Muthusaravanan, N. Sivarajasekar, J. S. Vivek, T. Paramasivan, Mu. Naushad, J. Prakashmaran, V. Gayathri, Omar K. Al Duaij, Environ Chem Lett, 16(4), 1339 (2018)

47. H. Ali, E. Khan, M. A. Sajad, Chemosphere, 91, 869 (2013)

48. X. Wan, M. Lei, J. Yang, Catena, 148(1), 67 (2016)

49. T. Tiecher, C. A. Ceretta, P. A. A. Ferreira, C. A. Lourenzi, T. Tiecher, E. Girotto, F. T. Nicoloso, H. H. Soriani, L. De Conti, T. Mimmo, S. Cesco, G. Brunetto, Geoderma, 262, 52 (2016)

50. A. Mojiri, J. Biol. Environ. Sci. 5(13), 17 (2011)

51. V. Sheoran, A. S. Sheoran, P. Poonia, Pedosphere, 26(2), 148 (2016)

52. S. Khalid, M. Shahid, N. K. Niazi, B. Murtaza, I. Bibi, C. Dumat, Journal of Geochemical Exploration, 182, 247 (2017)

53. A. Mahar, P. Wang, A. Ali, M. Kumar, A. Hussain, Q. Wang, R. Li, Z. Zhang, Ecotoxicol. Environ. Saf., 126, 111 (2016)

54. M. Rezvani, F. Zaefarian, AJAE, 2(4), 114 (2011)

55. H. Ali, M. Naseer, M. A. Sajad, Int. J. Env. Sci., 2 (3), 1459 (2012)

56. M. Shahid, C. Dumat, S. Khalid, N. K. Niazi, P. M. C. Antunes, Rev. Environ. Contam. Toxicol, 241, 73 (2016)

57. R. Sfiru, P. Cardei, V. Vladut, M. Matache, International Symposium ISB-INMA-THEH Procedings, Bucharest, Romania, 435 (2017)

58. D. M. Bordean, V. Vlăduţ, I. Caba, I. Gogoasa Alda L., C. Moldovan, D. Moigradean, L, Pirvulescu. Animal Science and Biotechnologies, 50, 162 (2017)

59. P. Cardei, C. Tudora, 7th International Scientific Conference Engineering for Rural Development, Jelgava, Lithuania, 893 (2018)

60. M. Sabir, E. A. Waraich, K. R. Hakeem, M. Öztürk, H.R. Ahmad, M. Shahid (Soil Remediation and Plants, Elsevier Inc. 2015) 
61. M. J. Blaylock, J. W. Huang, Phytoremediation of Toxic Metals: Using Plants to Clean up the Environment (John Wiley \& Sons Inc, New York, NY 2000)

62. Z. R. Holan, B. Volesky, Biotech. Bioeng., 43 (11), 1001 (1994)

63. L. Deng, Y. Su, H. Sua, X. Wang, X. Zhu, J. Hazard. Mater. 143 (1-2), 220 (2007)

64. J. Vymazal, Uptake of lead, chromium, cadmium and cobalt by Cladophora glomerata, Bull. Env. Contam. Toxicology, 44 (3), 468 (1990)

65. S., J. Dwivedi, Advanced Laboratory Res. Bio., 3 (3), 195 (2012)

66. A. Sánchez, A. Ballester, M. L. Blázquez, F. González, J. Muñoz, A. Hammaini, FEMS Microbiol Rev. 23(5), 527 (1999)

67. E. Fourest, B. Volesky, Appl. Biochemistry Biotech., 67 (3), 215 (1997)

68. K.V. Ajavan, M. Selvaraju, K. Thirugnanamoorthy, Pakistan J. Bio. Sci., 14 (16), 805 (2011)

69. T.A. Davis, B. Volesky, R. H. S. F. Vieira, Water Res., 34 (17), 4270 (2000

70. J. I. Kumar, C. Oommen, J. Env. Bio., 33 (1), 27 (2012)

71. B. V. Tangahu, S. R. S. Abdullah, H. Basri, M. Idris, N. Anuar, M. Mukhlisin, International Journal of Chemical Engineering, 2011 (31), 1 (2011)

72. H. Singh, A. Verma, M. Kumar, R. Sharma, R. Gupta, M. Kaur, M. Negi, S.K. Sharma, Austin Biochem, 2(2), 01 (2017)

73. M. A. Galende, J. M. Becerril, O. Barrutia, U. Artetxe, C. Garbisu, A. Hernández, J. Geochem. Explor. 145, 181 (2014)

74. E. Masarovicova, K. Kralova, M. Kummerova, Acta Physiol Plant, 32, 823 (2010)

75. M. Bandiera, C. Dal Cortivo, G. Barion, G. Mosca, T. Vamerali, Sustainability, 8(4), 357, (2016)

76. G. S. Bañuelos, H. F. Mayland, Ecotoxicol. Environ. Saf. 46, 322 (2000)

77. A. Vassilev, J. P. Schwitzguébel, T. Thewys, D. van der Lelie, J. Vangronsveld, ScientificWorldJournal 4, 9 (2004)

78. T. Vamerali, L. Marchiol, M. Bandiera, G. Fellet, N.M. Dickinson, P. Lucchini, G. Mosca, G. Zerbi, Italian J Agron, 7, 323 (2012)

79. P. Kidd, M. Mench, V. Álvarez-López, V. Bert, I. Dimitriou, W. Friesl-Hanl, R. Herzig, J. O. Janssen, A. Kolbas, I. Müller, S. Neu, G. Renella, A. Ruttens, J. Vangronsveld, M. Puschenreiter, Int J Phytoremediation, 17, 1005 (2015)

80. J. Vangronsveld, R. Herzig, N. Weyens, J. Boulet, K. Adriaensen, A. Ruttens, T. Thewys, A. Vassilev, E. Meers, E. Nehnevajova, D. van der Lelie, M. Mench, Environ Sci Pollut Res 16(7), 765 (2009)

81. L. Jennifer, J. L. Wood, W. Liu, C. Caixian Tang, A. E. Franks, AIMS Bioengineering, 3(2), 211 (2016)

82. K. Tsekova, A. Kaimaktchiev, A. Tzekova, Bioaccumulation of heavy metals by microorganisms, Biotechnol Biotechnol Equip., 12(2), 94 (2014

83. O. B. Ojuederie, O. O. Babalola, Int J Environ Res Public Health., 14(12), 1504 (2017)

84. M. Strouhal, R. Kizek, J. Vacek, L. Trnková, M. Němec, Bioelectrochemistry, 60, 29 (2003)

85. S. Özdemir, E. Kılınç, A. Poli, B. Nicolaus, Biorem J, 17(2), 86 (2013)

86. S. Banerjee, R. Gothalwal, P. K. Sahu, S. Sao, India. Adv Biosci Biotechnol. 06(02), 131 (2015)

87. S. Zhang, M.S. Reddy, J.W. Kloepper, Plant Soil, 262, 277 (2004)

88. A. Ullah, S. Heng, M.F.H. Munis, S. Fahad, X. Yang, Environ. Exp. Bot., 117, 28 (2015) 